\title{
NEPALI MIGRANT WORKERS AMID COVID-19 IN MAJOR DESTINATION COUNTRIES: A HUMAN SECURITY APPROACH
}

\author{
Gaurav Bhattarai ${ }^{1 *}$, Jeevan Baniya ${ }^{2}$ \\ ${ }^{1}$ Faculty, Department of International Relations and Diplomacy (DIRD) \\ ${ }^{2}$ Assistant Director, Social Science Baha; Faculty, Department of International Relations \\ and Diplomacy (DIRD), TU. \\ Corresponding author: gauravpraysforall@gmail.com.
}

\begin{abstract}
The global outbreak of novel coronavirus has exposed a severe crisis and threat in the human security of the thousands of Nepali workers abroad. It has challenged a rather limited conception and understanding of security in the context of Nepali migrant workers and has led to rethink policies and plans about safe, dignified, and managed migration. This article seeks to identify the situations of Nepali migrant workers in major destinations such as the Persian Gulf and Malaysia and discusses the factors that shape a sense of insecurity/security and dignity among them. In this article, first, we argue that Nepali migrant workers have become vulnerable due to the challenges and risks facing them related to infection and deaths, loss of jobs and income, lack of safe and dignified repatriation, no access to essential services including food, accommodation and health, unsafe working and living situation and discrimination and ill-treatments. Second, we highlight that the government of Nepal needs to effectively regenerate and exercise its labour diplomacy to make the destination countries more accountable to their responsibilities towards labour migrants and their human rights, and equally tailor its development policies to create adequate and decent opportunities within the country.
\end{abstract}

Keywords: human security - COVID-19- Nepali- protection of migrant workers labour diplomacy

\section{INTRODUCTION}

Although labour migration is a quest for security, it often exposes migrant workers to new risks and insecurities (Gasper \& Sinatto 2016). 
The global pandemic has exacerbated such risks and insecurities in an unprecedented way. Upon the same realization, this study uses the human security approach to explore the vulnerabilities of such risks to the well-being and dignity of Nepali migrant workers, in the major labour destinations. The language of human security does not just securitize the issues of migrant workers but also studies their lives and rights on the move. Marginal to the power centers (Oberoi 2010), during the COVID-19 pandemic, both the destination countries and sending countries miserably failed to protect their human and labour rights. Thus, this study aims to make a human security analysis of the condition of Nepali migrant workers in the major labour destinations during the pandemic. To fulfill the same objective, this paper discusses the fear of infections and deaths among the migrant workers; loss of jobs and its cascading effects; and psychological problems triggered by them. Also, the paper highlights how far Nepal's labour diplomacy has relieved the problems and challenges that the labour migrants have been facing in the pandemic.

Today, COVID-19 pandemic has permeated a grave crisis in people's social, economic, and political lives globally. Works, incomes, and livelihoods have been unprecedentedly impacted. It has already affected 2.7 billion workers, representing approximately $81 \%$ of the world's workforce (ILO 2020a). One of the vehemently affected and most susceptible to the pandemic is labour migration, which has been one of the key features of the Nepali economy. Over 4 million labour permits were issued for Nepali seeking to migrate for foreign employment in the last decade, with 3,888,035 males and 211,891 females. Nepal received 8.8 billion USD in fiscal year 2018/2019, which accounted for $28 \%$ of GDP for that year (MoLESS 2020). Other than India, the top destinations for Nepali migrant workers remain to be Qatar, Malaysia, Saudi Arabia, the United Arab Emirates (UAE) and Kuwait (MoLESS 2020). According to Nepal Labour Force Survey (NLFS) 2017/18, there are approximately 3.2 million migrants abroad, including those who migrated for work, education, or other reasons. The same study estimate suggests that over $37 \%$ of the total Nepali migrants are in India (CBS \& ILO 2019). Because of the COVID-19 pandemic, millions of Nepali migrant workers in destination countries have faced multiple forms of risks and challenges. Their human rights and security are also under great threat and at stake (Nepal et al. 2020). 
There are recognized and shared norms and legal instruments that make states responsible to guarantee migrants' socio-economic, physical, human and labour rights including their rights to basic and essential services (health, accommodation, food) along with the safe and dignified return to their home, in the situation of crisis like the current one. For example, the Foreign Employment Act 2007 makes the state responsible to rescue and repatriate the workers and its citizens in times of crisis and pandemic like COVID-19 (Foreign Employment Act 2007). Likewise, Convention on the Protection of the Rights of All Migrant Workers and Members of their Families 1990; International Covenant on Civil and Political Rights (ICCPR); Charter of the United Nations; Universal Declaration of Human Rights (UDHR); Convention against Torture Other Cruel Inhuman or Degrading Treatment (CAT); International Convention on the Elimination of All Forms of Racial Discrimination (ICERD); Convention on the Elimination of All Forms of Discrimination Against Women (CEDAW); UN Convention Against Transnational Organized Crime: Protocol to Prevent, Suppress and Punish Trafficking in Persons, Especially Women and Children; International Covenant on the Rights of Persons with Disabilities; Global Compact for Migration (GCM); as well as recently issued key legal considerations on access to territory for persons in need of international protection in the context of the COVID-19 response, $16 \mathrm{March}$ 2020 ; Age, Gender and Diversity Considerations - COVID-19, 21 March 2020; and Gender-based violence prevention, risk mitigation and response during COVID-19, 26 March 2020 etc. have stated that both the countries of origin and countries of destination are obliged to protect various rights of migrants such as right to health, labour rights, social rights, guarantee right to leave any state and to re-enter their home state, protection against stigmatization or violence, proper living and working conditions, right to information and right to privacy etc. The government of Nepal and its diplomatic missions have made their efforts to protect the migrants and their rights in consultations with the state of destination countries (Nepal et al. 2020). However, like never before, the impacts of the COVID-19 on migrants have laid bare the stark reality of precariousness and insecurity that migrant workers and their families have been living under. Further, it has revealed and posed the question on the notion of (in) security of migrants, which has usually been defined in a very limited sense. 
Security essentially is a contested concept. It has been defined variously (Buzan 1982) and it has no universally agreed meaning (Wolfer 1962). Still, human security is broadly perceived to have encompassed the concept of securing and protecting people from the threat of a pandemic, risks of environmental degradation, and dangers of the outbreak of infectious diseases, ethnic conflict, among others (Commission on Human Security 2003). Globally, there is a wider consensus that freedom from fear, survival, livelihood, and dignity of people in general, which are fundamental and essential elements, need to be ensured in these situations (UNDP 1994). Nevertheless, these building blocks of security have been severely threatened and come under stress, due to the spread of infection, deaths, lockdown, job loss, hunger, the shutdown of industries, economic meltdown etc.

What differentiates the human security framework from the conventional security system, is the former's priority on freeing individuals from 'fear', 'want', and 'indignities' (UNDP 1994). Assessing the impact of global pandemic on the livelihood of migrant workers in major destination countries, it has been discovered that all such priorities and approaches have been overlooked, primarily by the destination countries' failure in including migrant workers in their national recovery plan, and sending countries' delays and ineffective responses including in repatriating the migrant workers in problems and risks. As a result, Nepali migrant workers had to face loss of job and income, whose cascading effects on them and their family back home, is undeniably a loss of 'freedom from want'. As a large chunk of migrant workers have been infected by COVID-19 and died in the major destination countries, Nepali migrant workers are persistently gripped by the fear of being infected and fear of death. Having lodged in unsafe places and overcrowded spaces, they are extremely prone to bad health and undernourishment (Hargreaves et al. 2020). Pandemic prejudices and 'blame game' against migrant workers get transformed into stigmatization, assuring no 'freedom from indignities'. As stigma tags a migrant worker as an undesired person in the host community, health inequalities are magnified, and stigmatic suspicion of migrant workers as the disease-carriers may inspire new modes of ethnic profiling (Vertovec 2020), increasing the mental and psychological problems for the migrant workers. 
Human Security is people-centred in terms of respecting human lives, involves looking at individual persons, commits for human dignity and human rights. It emphasizes on the objective and subjective focus on people's security, rather than only on national security or state security or economic security. Rejecting methodological nationalism, human security analysis embraces a methodological individualism (Gasper \& Sinatti 2016), with the focus on lived experiences. Thus, offering a migrant-centred approach, we try to illustrate key reasons, circumstances, and factors that shape the sense of (in) security among Nepali migrants, particularly in crisis situations like the COVID-19 pandemic. Based on the lessons learned in the context of the COVID-19, we discuss what it implies for labour diplomacy.

\section{METHODS}

This paper is based on the information collected, both from primary and secondary sources, to critically discuss the impacts of COVID-19 on the Nepali migrant workers in the major destination countries. Reports of ILO, UN, IOM and NHRC have been reviewed. Data of the MoHP, CCMC and non-resident Nepali association have been used to describe the number of deaths, infections and repatriation of Nepali migrant workers. Besides, conventions, agreements and treaties on human rights and labour migration, notices and data published by the government agencies, have been reviewed. Also, the decisions of the different parliamentary committees, government's reports, statistics, and guidelines have been studied and analysed. Media sources were also reviewed to understand various issues of Nepali migrants. The themes that emerged from the reviews were thematically analyzed and interpreted.

\section{RESULTS}

\section{Fear of life: Infection and deaths}

What injects a perceived or actual sense of insecurity among Nepali migrant workers is fear of infection and death from COVID-19. Since the outbreak of the coronavirus, a total of 474 Nepali migrant workers succumbed to the virus until July 24, 2020 in various destination countries, out of which, 459 are men and 15 are women. As they have to live and work in the crowded camps and workplaces without proper protective measures, they feel at risk(Mandal 2020e, Nepal et al. 2020). The migrants in GCC 
countries feel more vulnerable and are also at the risks of infection in some of these countries due to the high infection rate in these countries (Karki 2020) and many of them were living in constant distress and disturbed situations (Pant 2020, Nepal et al. 2020).

Despite WHO's call for the need to ensure adequate access to health services, migrant workers lack adequate testing and treatments in the hospitals of the destination countries as they are not included in national public health systems (Kluge et al. 2020). Nepali workers in various destination countries are at increased risks of infections and health due to unsafe environment and hygiene. Their work and living spaces are crowded and are not provided protective equipment. In one of the companies in Kuwait, Nepali migrants have no option but to live with those who have shown some symptoms of the virus, and the ones who show symptoms are even not taken for the check-ups. Hence, Nepali feel unsafe and worried (Nepal et al. 2020). Having lost their jobs and income, the returnee migrant workers had the fear of death, and fear of infection, as their co-workers residing in the shared camps had been infected (Baniya et al. 2020, Nepal et al. 2020).

\section{Loss of job, income, and its cascading effects}

An estimate suggests that at least $25 \%$ of the Nepali are to lose their employment abroad due to a decline in the economic growth mainly in the GCC countries, where about 1,425,000 Nepali work. Nearly 280,000 Nepali have already lost their jobs in these countries because of the pandemic (ILO 2020a). According to the Nepal Association of Foreign Employment Agencies, 10-30 \% of jobs held by Nepali in Malaysia and Gulf have gone (Shrestha 2020). Further, some reports suggest, while thousands of Nepali have already lost their jobs, many of them have lost a full-time job or have been laid off from the job, or their salary has been deducted (Mandal 2020a) or forcefully asked to be on unpaid leave, and they have not been paid for months (Nepal et. al. 2020). There have been 20-80\% cuts in the salaries of Nepali in the destination countries. The cut ranges from $30-50 \%$ in the UAE, 20-40 \% in Qatar, 50-80\% in the Maldives (Baniya et. al. 2020). Most affected Nepali who lost their employment in the UAE used to work in the saloon, clothes stores, construction sector, as beauticians, and taxi drivers. 
There are around 600 Nepali involved in the taxi driving profession; but due to the lockdown, their taxis are grounded, while they are unable to pay installments (Baniya et. al. 2020). In Qatar, Nepali who used to work in the textiles, malls, construction, facility, cleaning have been most affected. It meant huge ramifications on the security and livelihood of the millions of migrants and their left-behind members, who are dependent on the former (Pant 2020).

\section{Returning home and sense of security}

Both Nepal, and the countries of major destinations of Nepali migrant workers, introduced lockdowns, to mitigate and prevent the further spread of the virus. Some of the countries enforced partial or full lockdowns, closure of borders, curfews, restrictions on motilities and (physical) social distancing, travel bans etc. (Baniya et al. 2020, India Today 2020). The impositions of these measures not only affected the work, income, and livelihood of Nepali migrant workers but also restricted the motilities of migrant workers within destination counties as well as to and from Nepal.

The government of Nepal enforced various measures including the closure of international flights since 20 March 2020, which meant all kinds of on-arrival visas were also suspended (Embassy of Nepal in Qatar 2020) and new labour permits were not issued. The travel restrictions led to situations, where millions of migrants and mostly migrant workers got stranded in various destination countries. According to the Nepal government's preliminary estimation, there were a total 407,000 migrants expected to return; this included at least 127,000 workers in need of immediate repatriation and about 280,000 Nepali who lost their jobs in GCC and Malaysia alone (Mandal 2020b). Also, destination countries including Qatar and Kuwait granted a general amnesty to migrant workers (Mandal 2020j) and expressed their intention to even support their repatriation through their own flight (Mandal 2020c). Further, around 1,500 labour permits of Nepali expire every day (Baniya et. al. 2020), and approximately 90,000 migrant workers' visas have already expired. This implied huge challenges on the part of the government in terms of repatriation, testing, and quarantines as well as rehabilitation and (economic, social, and psychosocial) integration. 
Death rites play an important role in Nepali culture because they don't end with a burial alone. But because of the lockdowns and travel bans, until July 24, 2020, the dead bodies of 165 migrants have been cremated in the destination country, without the presence, but with the consent of family members (Foreign Employment Board 2020). Dead bodies of 216 migrant workers from major destination countries have been already repatriated, and handed over to the families. Still, 94 dead bodies are stranded and waiting to be repatriated (Foreign Employment Board 2020). This situation is against the migrants' right to return guaranteed in the FEA 2007, the 1990 convention related to the rights of migrants and their families and ICCPR (Baniya et al. 2020, Nepal et al. 2020).

\section{Mental and psychosocial problems and threat to dignity}

Various cases of discrimination and social stigma (ILO 2020c, The Business Standard 2020), and violence against migrant workers (Kuo\& Davidson 2020) that were reported during the COVID-19 pandemic that have resulted into the loss of 'freedom from indignity'. Such a threat to dignity, during the pandemic, signals the absence of human security frameworks (Tadjbakhsh 2014) in addressing the issues of migrant workers in the receiving countries. Instead of effectively implementing the international human rights norms of "non-discrimination" (ILO 2007), it is reported that Nepali migrant workers have been subjected to various forms of stigmatization and have been victims of violence and hatred in the destination countries, which makes them feel unsafe and insecure (ILO 2020c). Qatar used the global pandemic of Covid-19 as a plot to expel Nepali migrant workers illegally (Amnesty International 2020). These are clearly the violations of labour rights and breaches of contracts. Such decisions will have durable effects on migrant workers, their families, and their communities (Yayboke 2020).

In Ajman of UAE, a Nepali migrant worker even committed suicide after being harassed and ill-treated by co-workers as he was perceived to have been treated with the virus in the hospital (Nepal et al. 2020). In Kuwait, Qatar, the UAE, Maldives, many Nepali who have lost their jobs, stranded and unable to return, are unable to pay the loan (taxi drivers) and insurance and house rent (living outside the labour camps); 
pregnant women and domestic workers, and those whose employers are not going to provide their return tickets, are increasingly worried and distressed (Nepal et al. 2020). Further, those workers with pregnancy in the UAE, who needed regular medical checkups and proper nutrition and care, are not able to bear the expenses, hence are found to be under mental and psychosocial problems. For example, a female domestic worker from Nepal in the UAE, who had an unfortunate incident of miscarriage was further distressed as she, without any insurance, was unable to pay back Dirham 17,000-18,000 (USD4628 - 4900) (Nepal et al. 2020).

\section{Guardianship and trust with the state and sense of security}

Amid the COVID-19 crisis, the government of Nepal and its diplomacy is perceptively limited to informing the migrant workers that they need to cope with the crisis in the destination counties, and calling on the receiving states, despite the latter's reservations, to protect the security of Nepali labourers abroad, and collecting the data of stranded migrants for repatriation.

This does not, however, represent the reality. Although quite late, the government and its agencies have carried out several efforts. For example, Nepal's High-Level Coordination Committee for Prevention and Control of Covid-19, on March 24, 2020, informed the Nepali migrant workers to remain safely where they were, and appealed to the destination countries for their safety. Nepal's diplomatic missions have been directed to be in constant touch with the migrant workers for crucial information and support (Khadka 2020, Nepal et al. 2020) and they are also engaging with countries of destinations for ensuring basic services and protection for stranded migrants (Kamat 2020). The government decided to start repatriating its citizens, for which groundwork was laid out in coordination with relevant ministries as well as diplomatic missions including the necessary budget for new fiscal year 2020/21 (GoN 2020). PM Oli and Nepal's foreign minister also communicated with their counterparts in the destination countries (Ministry of Foreign Affairs 2020) requesting for the social protection and medical care of the Nepali migrant workers, and asking for the cooperation in matters of employment and job security of Nepali workers. The Ministry of Labour, Employment and Social Security (MOLESS) and diplomatic 
missions in various destination countries have been collecting data about Nepali' problems and need for immediate repatriation (Embassy of Nepal in Malaysia 2020; Nepal et al. 2020). The GoN has been consulting with the governments in destination countries over the issue of treatment, visa and work permits, and repatriation. Reportedly, different ministries have been working on socio-economic reintegration for migrants (Baniya et al. 2020).

Nepal's labour diplomacy, which was merely confined to regulating labour migration before the COVID-19 pandemic, now confronts a major challenge of repatriating the stranded migrant workers, and those who have lost their jobs and income. But, Nepali diplomatic missions in the major labour destination countries are already under-staffed and under-resourced, which may further aggravate the challenge to successfully engage with the receiving countries, in addressing the assorted issues of Nepali migrant workers (Mandal 2020c) and make the receiving countries accountable to the protection and security of Nepali migrant workers (Nepal et al. 2020). Migrant workers, particularly in those countries, where Nepal has no diplomatic missions, are worried about their situation and uncertain return, which is further aggravated by the lack of proper and authentic information (Baniya et al. 2020). Hence, they are getting increasingly frustrated and worried. The state and Nepali missions' constant concerns about and communication with the migrants can play crucial roles in terms of building a sense of being cared for and safe. It also serves as confidence and trustbuilding between citizens and the state as guardian.

Assessing Nepal's labour diplomacy and its roles to protect the human security of migrant workers during the pandemic, it has been realized that Nepal's labour diplomacy in the major destination countries has been quite restricted in terms of orientations and engagements. Although labour diplomacy involves the relations between sending and receiving states (Adamson \& Tsourapas 2018), it is not necessarily confined to that, as labour diplomacy also links international organizations (Hamilton \& Langhorne 2011) including ILO and IoM. More precisely, labour diplomacy is driven by the diplomatic means, and methods to achieve the migration goals (Tsourapas 2018). But, Nepal's migration goals have been constrained to drawing more remittances without paying necessary attention to the security of the migrant workers. As a result, labour migrants are considered 
as a commodity for export by the country (Seddon 2005), and Nepal is identified as a labour sending country from the global south. The COVID-19 pandemic largely exposed the fissure in Nepal's labour diplomacy and how it has failed to address the security of the migrant workers. The objective of human security itself is to safeguard the vital core of all human lives from pervasive threats (Alkire 2002) or in other words, to protect the vital core of all human freedoms and human fulfillment (Commission on Human Security 2003). But, Nepal's labour diplomacy has largely been ineffective in protecting migrant workers from the critical threats of hunger, infection, job loss, and deaths in the major destination countries. For a long time, dead bodies of Nepali migrant workers stuck abroad as the government failed to bring them home (Khadka 2020). Although the government started giving permits to the chartered flights from mid-June, the task of repatriating workers has not finished yet as the government estimates that between 400,000 and 1 million need to return (Gill \& Sapkota 2020). Also, Nepal's labour diplomacy in major destination countries failed in creating a favorable environment that could give migrant workers the building blocks of survival. While some of the migrant workers weren't able to buy a chartered flight ticket to get back home, the Supreme Court ordered the government to pay for tickets by using the foreign employment welfare fund to repatriate Nepali workers living in highly vulnerable conditions (Prasain \& Mandal 2020a). It was only after two weeks that the government decided to bear all the cost of bringing home the Nepali workers who had gone on foreign employment and rendered jobless within a year due to the pandemic (Mandal 2020g). Thus, the Nepali missions in major labour destination countries, at present, are limited to ascertaining whether the migrant workers seeking repatriation are really stranded without money after being unpaid by their employers, or have lost their jobs and haven't received any support from anywhere. Even the government's decision to resume labour migration, which has been entirely suspended since March 2020 owing to the Covid-19 lockdown and international travel restrictions, indicates premature labour diplomacy. Labour migration experts believe that the decision to resume labour migration has been taken at the cost of the health and safety of the migrant worker during this pandemic. Although human security places individuals as the key point of reference, and assumes that the safety of the individual is the key to national and international security, Nepal's labour 
diplomacy still places state interests above the security of the individual migrant workers. Today's Nepali state's interest lies in combating the sharp fall of the inflow remittances by sending more migrant workers to the major destination countries, as the government's decision to resume foreign employment applies to all those migrant workers who are home on leave as well first-timers (Mandal 2020h). While numerous Nepali migrant workers are infected with the coronavirus in the destination countries, Nepal's labour migration should have concentrated on applying safety issues to their accommodation, which is usually squalid and mostly crowded. It is the responsibility of the Nepali missions in the major destination countries to constantly monitor the workplace and accommodation provided to the migrant workers, the financial condition of the employers, and assess the response of the employers during the pandemic (Mandal 2020h, Nepal et al. 2020). As Nepal has been repatriating stranded workers back, sending them to foreign employment without Nepali mission probing employers' status, would only make workers struggle without money, food, shelter, and health treatment (Mandal 2020i). In the absence of such enquiry and assessment, Nepal migrant workers will be only vulnerable, getting their overall livelihood and well-being impacted. As Nepali missions abroad have to conduct the risk assessment before resuming the foreign employment, sending migrant workers, at present, will further burden the overstrained missions. Earlier too, during the pre-repatriation phase, their challenge mounted with the uncertainty about the modality of migrants' home-coming, covering air tickets, medical examinations, and flight dates of the migrant workers requesting repatriation (Prasain \& Mandal 2020b).

As labour diplomacy aims to link state's diplomacy with the international organizations too, Nepali diplomatic missions in major destination countries had a sigh of relief recently, upon knowing that ILO has initiated a project to address the problem of repatriation in coordination with embassies abroad and non-residential Nepalese associations (Nepali Times 2020). The project intends to support Nepal's diplomatic mission in the major destination countries by providing volunteer staff. ILO's project also extends the embassy's reach beyond the capital by setting up outreach camps where migrant workers are largely concentrated. Easing the task of Nepal's missions abroad, ILO project also facilitates mediation 
with employers and ensures safe and humane reception of returnees at the holding centres, and to home districts (Nepali Times 2020).

\section{DISCUSSION}

The observation has demonstrated that in GCC and Malaysia, the migrant population has been devastatingly affected due to the impacts of the pandemic including in terms of infection and deaths. As of July 11, 2020, a total of 25000 Nepali was infected in key destination countries including Kuwait, Saudi Arabia, Bahrain, UAE, Qatar, and Malaysia (NRNA 2020). 474 Nepali migrant workers died because of the virus until July 24, 2020 (FEB 2020). With the start of the repatriation of Nepali stranded abroad, from June 10, 2020, over 215 dead bodies have been repatriated and handed over to the families of the deceased (FEB 2020). But, still above 90 dead bodies of migrant workers are stuck in various destination countries (FEB 2020, Mandal 2020k). It has been reported that until July 20, 2020, about 31,000 Nepalese migrant workers have been repatriated (CCMC 2020). About 1500 to 2500 Nepali migrant workers are repatriated each day from Gulf countries and other major destinations. The returnees have been kept at quarantine centers and returning migrant workers testing positive are isolated (WHO 2020). Those returnees, who were quarantined, often face the problem of not being accepted easily in the community (Nepal et al. 2020). Also, the widespread incidents of violations of labour rights in the form of forceful expulsion from the employment, or deducted salary, the threat of deportation, lack of access to essential services, discriminations against the migrants, physical and emotional victimizations of Nepali migrant workers at the hands of sending and destination countries, are selfillustrative to establish that there is a long way to go in terms of protecting the rights and dignities of Nepali migrant workers, particularly in the context of crisis.

From the study, it becomes evident that repatriation of the migrant workers mostly in vulnerable situations is unavoidable, and the fact that the number of those in need of repatriation by the government or those willing to return on their own will seem to be growing day by day. Hence, without any preparation based on the objective assessment of the situation in the destination countries, the process is going to be complicated, and the burden is going to be piled up in the part of the government, for their 
repatriation and testing and quarantines upon their return. But, it is urgent that Nepali in difficulties and distress are repatriated as soon as possible, which will also be in line with the Supreme Court's interim order for the same (Sharma 2020).

Learning lessons from these experiences and with the aim of protecting the migrants in situations like this pandemic, existing labour agreements and MOUs between Nepal and destination countries will have to be reviewed and revised if necessary. It requires redefining the whole concept and approaches of ensuring security of migrant workers, and making Nepal's foreign policy itself believe in the 'safeguarding of the rights of the Nepalese people' inside and outside of the country (The Himalayan Times 2020). Based on the objective review of efforts and treatment towards the Nepali migrant workers in the destination countries during the situation of crisis, the government of Nepal can also reconsider the idea of whether to send the Nepali migrant workers to those countries, where Nepali migrant workers were subjected to exploitation and violations of labour agreements, and human rights, and the states were not serious enough to address the problems and challenges facing the migrants.

It is noted that more proactive diplomacy and political engagement with the government of the destination countries will be crucial for the safe repatriation of the migrants, and also in the days ahead, in regards to safeguarding the migrants and their rights. Nevertheless, such efforts could have provided better results, if necessary precautions and assessment of the situations were made in advance, and preparation could have been done for their repatriation. In regard to the safety of those, who are and will continue in their employment in the destination countries, it is clear that employers undertake necessary measures for mitigating the contagion as specified in the ILO's guidelines (ILO 2020b) about the Occupational Health Safety (OHS) in living and working spaces, and avoid the risks of a risky environment due primarily to the lack of social distancing and lack of personal protective equipment (PPE). Also, it is important that risks are assessed and the OHS situations are monitored regularly, including the participation of the migrants. The role of diplomatic missions seems to be crucial to this end. If such measures are not ensured, it will be wise to facilitate their return to Nepal, for the sake of their safety. 
The decline in the job opportunities along with the perceived and actual risks leading to millions of Nepali returning to Nepal from abroad in the near future, could be an opportunity for the Himalayan country to not only develop policies to respond to immediate damages but also to improve public policies and services namely related to employment, employment-intensive programmes, education and life skills, agriculture and development policies - important also for achieving sustainable development goals. Macro and micro-economic policies could be adjusted to prevent millions of youths, including returnee migrants from being trapped into the 'lockdown generation,' by creating and further retaining opportunities. For the stimulation of the economy at home, decent employment and entrepreneurship opportunities for workers, including those who return from the foreign employment should be prioritized, and any recovery packages and plans need to also consider up skilling and utilization of their skills after their return - which is also in line with the principle of the right to work guaranteed by the Constitution of Nepal 2015 (Mandal 2020f). The vulnerabilities of working-class people amid the pandemic also call for the improvement of coverage and quality of social protection and workers' rights and labour market relations (Mandal $2020 \mathrm{~d}$ ).

Nepali migrant workers facing a multiplicity of problems, as discussed in the preceding sections, is still a serious issue, and is going to be complicated further. Hence, the Government of Nepal should be already thinking through the ways and mechanisms to address the issues of remedies for thousands of migrants, including the improvement of free legal services to the migrants and their families as set up previously by the government of Nepal (The Kathmandu Post 2018). Taking into consideration the huge volume of grievances, attempts to redress many of the disputes through diplomatic means and challenges look imminent and practical.

\section{CONCLUSION}

By using a qualitative method, the article tried to illustrate situations of Nepali migrants in the GCC and Malaysia. Evidence of Nepali migrant workers in GCC countries and Malaysia in the context of COVID-19 suggests that economic and life-related vulnerabilities and insecurity have further deteriorated due to the adverse impacts of the COVID-19 pandemic. They have faced multiple problems including the loss of employment and 
income. They are deprived of basic services and are accommodated in unsafe conditions in the workplace, being exploited. They are stranded and unable to return home amid the problems faced. Lack of adequate support and efforts towards the protection of Nepali migrants from the agencies of the government of Nepal and those of destination countries has added further uncertainties in their security and mistrust on these agencies.

The experiences of Nepali migrant workers during the pandemic indicates that mere provision and existence of national and internal instruments and frameworks, as well as bilateral labour agreements aimed at ensuring the protection of labour and human rights of migrant workers is useless, unless it is strictly enforced and implemented by the state parties. In addition, it necessitates, on the one hand, an exercise of proactive labour diplomacy consisting of engaging diaspora, and other stakeholders for making the destination countries more accountable towards Nepali workers, on the other hand for adequate preparedness on the part of the government of Nepal. Such preparedness can entail serious review and shifts in policies and practices for ensuring protection of migrants and their rights, capacity enhancement of diplomatic missions of Nepal in key destination countries, coordination with like-minded migrant sending countries as well as international communities etc. Most important of all, the fact that the evidence has reinforced the government's existing policy of ending 'forced migration for employment'. Hence, public policy responses from the governments of Nepal should be such that it provides opportunities for youths at home and mitigates involuntary migration abroad.

\section{REFERENCES}

Adamson, Fiona B \& Tsourapas, Gerasimos. (2018). The migration state in the global south: Nationalizing, developmental and neoliberal models of migration management. International Migration Review. doi: https://doi.org/10.1177\%2F0197918319879057. (Accessed: 18.06.2020)

Alkire, Sabina. (2002). Dimensions of human development. World Development, 30(2): 181-205, SSRN: https://ssrn.com/ abstract $=2118655$. (Accessed: 21.06.2020) 
Amnesty International. (2020). Qatar: Migrant workers illegally expelled during COVID-19 pandemic. https://www.amnesty.org/en/latest/ news/2020/04/qatar-migrant-workers-illegally-expelled-duringcovid19-pandemic/ (Accessed: 24.07.2020)

Baniya, J., Bhattarai, S., Thapa, B.J., Pradhan, V., Gurung, M., Dogendra Tumsa, D., et al. (2020). COVID-19 and Nepali labour migrants: impact and responses. Center for the Study of Labour and Mobility, Kathmandu. https://www.ceslam.org/our-publications/covid-19and-nepali-labour-migrants. (Accessed: 05.08.2020)

Booth, K. (1991). Security and emancipation. Review of International Studies, 17(4). https://doi.org/10.1017/S0260210500112033. (Accessed: 08.06.2020)

Buzan, B. (1982). People state and fear: The national security problem in international relations. Wheatsheaf Book Ltd, Sussex.

CCMC. (2020). Press release: COVID-19 crisis management center. https:// ccmc.gov.np/press_release2.html. (Accessed: 24.07.2020)

CBS \& ILO. (2019). Report on the Nepal labour force survey 2017/18. Central Bureau of Statistics. https://nepalindata.com/media/ resources/items/20/bNLFS-III_Final-Report.pdf. (Accessed: 24/06/2020)

Commission on Human Security. (2003). Human Security Now. https:// reliefweb.int/sites/reliefweb.int/files/resources/91BAEEDBA50C 6907C1256D19006A93 53-chs-security-may03.pdf. (Accessed: 20.06.2020)

Embassy of Nepal in Malaysia. (2020). Notice. Nepalese in Malaysia to Provide their Information. https://my.nepalembassy.gov.np. (Accessed: 12.07.2020)

Embassy of Nepal in Qatar. (2020 March 13). Urgent Notice Regarding Travel Restriction Related to Covid-19. https://qa.nepalembassy. gov.np/urgent-notice-regarding-travel-restriction-related-to-covid19-dated-13th-march-2020-1215-hrs-nst/(Accessed: 28.06.2020)

Foreign Employment Act. (2007). Provisions on sending workers back to Nepal. http://ilo.org/dyn/natlex/natlex4.detail?p_lang=en\&p_ isn=78258\&p_country=NPL\&p_count=120(Accessed: 18.06 .2020 ) 
Foreign Employment Board. (2020). Press release. http://www.fepb.gov.np/ detail/76/suchana. (Accessed: 24.07.2020)

Gasper, D., \& Sinatto, G. (2016). Investigating migration within a human security framework. Migr. Desarro, 14(27):19-63. http://www. scielo.org.mx/pdf/myd/v14n27/1870-7599-myd-14-27-00019.pdf (Accessed: 18.07.2020)

Gill, P. \& Sapkota, J.R. (2020). COVID-19: Nepal in crisis: The diplomat. https://thediplomat.com/2020/06/covid-19-nepal-in-crisis/ (Accessed: 18.07.2020).

GoN. (2020). Budget Speech of Fiscal Year 2020/21. Ministry of Finance. https://mof.gov.np/uploads/document/file/ (Accessed: 28.06.2020).

Hamilton, K. \& Langhorne, R. (2011). The practice of diplomacy: Its evolution, theory and administration. Routledge, London.

Hargreaves, S., Dominik, Z., Kolitha, W. \& Anna, D. (2020). Targeting COVID-19 interventions towards migrants in humanitarian settings. The Lancet. DOI: 10.1016/S1473-3099(20)30292-9 (Accessed: 22.07.2020)

ILO. (2014). Labour migration for employment: A status report for Nepal 2013/14. International Labour Migration. https://www.ilo. org/kathmandu/areasofwork/labour-migration/lang--en/index. $\mathrm{htm}$ (Accessed: 16.07.2020)

ILO. (2007). International Labour Standards on migrant workers' rights: Guide for policymakers and practitioners in Asia and the Pacific. https://www.ilo.org/asia/publications/WCMS_146244/lang--en/ index.htm (Accessed: 21.06.2020).

ILO. (2020a). ILO Monitor: COVID-19 and the world of work. 2nd Edition. https://www.ilo.org/global/topics/coronavirus/impactsand-responses/WCMS_740877/lang--en/index.htm (Accessed: 21.06.2020)

ILO. (2020b). In the face of a pandemic: Ensuring Safety and Health at Work. https://www.ilo.org/wcmsp5/groups/public/---ed_protect/--protrav/---safework/documents/publication/wcms_742463.pdf (Accessed: 28.06.2020) 
ILO. (2020c). Impact of COVID-19 on Nepali Migrant Workers: Protecting Nepali Migrant Workers during the Health and Economic Crisis. https://www.ilo.org/wcmsp5/groups/public/---asia/---ro-bangkok/--ilo-kathmandu/documents/briefingnote/wcms_748917.pdf (Accessed: 18.06.2020)

India Today. (2020). Some relief for industries, flights, trains remain suspended: Govt issues detailed guidelines on lockdown. https://www.indiatoday.in/india/story/govt-mha-issuesdetailed-guidelines-on-lockdown-1667092-2020-04-15f (Accessed: 28.06.2020)

Kamat, R.K. (2020). SC asks govt to bring back migrant Nepali stranded in foreign lands. The Himalayan Times. https://thehimalayantimes. com/nepal/supreme-court-asks-government-to-bring-backmigrant-nepalis-stranded-in-foreign-lands/(Accessed: 24.07.2020)

Karki, H. (2020 May 23). Over 6900 Nepali infected in Qatar by coronavirus. Kantipur Daily. https:/ekantipur.com/news/2020/05/23/15902126 4966971490.html(Accessed: 24.06.2020)

Khadka, R. (2020). 100 plus migrant workers' dead bodies await repatriation. Republica. https://myrepublica.nagariknetwork. com/news/100-plus-migrant-workers-dead-bodies-awaitingrepatriation/ (Accessed: 18.07.2020)

Khadka, U. (2020). Preparing for Nepal's returnees. Nepali Times. https:// www.nepalitimes.com/here-now/preparing-for-nepals-returnees/ (Accessed: 24.06.2020)

Kluge, H.H.P., Zsuzsanna, J., Jozef, B., VeronikaD, A. \& Santino, S. (2020). Refugee and migrant health in the COVID-19 response. The Lancet. 3095(10232). doi.org/10.1016/S0140-6736(20)307911 (Accessed: 22.06.2020)

Kuo, L. \& Davidson, H. (2020). They see my blue eyes then jump back' China sees a new wave of xenophobia. https://www.theguardian. com/world/2020/mar/29/china-coronavirus-anti-foreigner-feelingimported-cases (Accessed: 22.06.2020) 
Mandal, C.K. (2020a May 18). Without work and salary, Nepali migrants protest in Covid-hit UAE. The Kathmandu Post. https:// kathmandupost.com/national/2020/05/18/without-work-andsalary-nepali-migrants-protest-in-covid-hit-uae (Accessed: 22.06.2020)

Mandal, C.K. (2020b May 09). Thousands of Nepali migrant workers from Persian Gulf and Malaysia expected to return home soon. https:// kathmandupost.com/national/2020/05/09/thousands-of-nepalimigrant-workers-from-persian-gulf-and-malaysia-expected-toreturn-home-soon. (Accessed: 28.06.2020)

Mandal, C.K. (2020c May 05). Government considers bringing back Nepali migrant workersfrom Covid-19-affected countries. The Kathmandu Post. https://kathmandupost.com/national/2020/05/05/ government-considers-bringing-back-nepali-migrant-workersfrom-covid-19-affected-countries. (Accessed: 22.07.2020)

Mandal, C.K. (2020d June 25).Worker-sending countries like Nepal brace for migrant crisis within Covid-19 crisis, ILO warns. The Kathmandu Post. https://kathmandupost.com/national/2020/06/25/ worker-sending-countries-like-nepal-brace-for-migrant-crisiswithin-covid-19-crisis-ilo-warns. (Accessed: 22.07.2020)

Mandal, C.K. (2020e March 26). Nepali in Qatar live in overcrowded and squalid conditions even during pandemic. The Kathmandu Post. https://kathmandupost.com/national/2020/03/26/nepalis-inqatar-live-in-overcrowded-and-squalid-conditions-even-duringpandemic (Accessed: 22/07/2020)

Mandal, C.K. (2020f May 29). Government eyes massive 700,000 jobs within the country. The Kathmandu Post. https://kathmandupost. com/national/2020/05/29/government-eyes-massive-700-000jobs-within-the-country?fbclid=IwAR0CTe5-5dstQ736asIPxzQdaWuDRc9vBxl-FAb6Ne2_89ZFAFdGVAFDWk. (Accessed: 28.06.2020)

Mandal, C.K. (2020g July 01). Guidelines ready for repatriation of migrant workers who cannot pay for their flights. The Kathmandu Post. https://kathmandupost.com/national/2020/07/01/guidelines-ready- 
for-repatriation-of-migrant-workers-who-cannot-pay-for-theirflights (Accessed: 12.07.2020)

Mandal, C.K. (2020h June 22). Labour migration experts criticise government decision to resume foreign employment. The Kathmandu Post. https://kathmandupost.com/national/2020/06/22/ labour-migration-experts-criticise-government-decision-toresume-foreign-employment. (Accessed: 24.07.2020)

Mandal, C.K. (2020i April 16). We don't want to die in this desert: Nepali workers in the UAE plead to be brought home. The Kathmandu Post. https://kathmandupost.com/national/2020/04/16/we-don-twant-to-die-in-this-desert-nepali-workers-in-the-uae-plead-to-bebrought-home(Accessed: 12.07.2020)

Mandal, C.K. ( 2020j June 12). Over 300 Nepali workers return home from Kuwait. The Kathmandu Post. https://kathmandupost.com/ national/2020/06/12/over-300-nepali-workers-return-home-fromkuwait (Accessed: 6.07.2020)

Mandal, C.K. (2020kJune 28). Repatriation of bodies ofmigrant workers who died abroad resumes. The Kathmandu Post. https://kathmandupost. $\mathrm{com} /$ national/2020/06/28/repatriation-of-bodies-of-migrantworkers-who-died-abroad-resumes (Accessed: 20.06.2020)

Ministry of Foreign Affairs. (2020). Press release on foreign minister Gyawali's telephone conversation with Saudi foreign minister. https://mofa.gov.np/press-release-on-on-foreign-ministergyawalis-telephone-conversation-with-saudi-foreign-minister/ (Accessed: 20.05.2020)

MoLESS. (2020). Nepal labour migration report 2020. Ministry of Labour, Employment and Social Security, Government of Nepal, https:// moless.gov.np/wp-content/uploads/2020/03/Migration-Report2020-English.pdf (Accessed: 20.06.2020)

National Planning Commission (NPC) Member. (2020). Briefing in Webinar.

Nepali Times. (2020). Helping hands for Nepali migrants in distress. Nepali Times. https://www.nepalitimes.com/latest/helping-handfor-repatriated-nepali-workers/(Accessed: 24.07.2020) 
Nepal, R., Baniya, J. \& Kshetri, K.T. (2020). Kovid-19 mahamariko chapetama nepali aaprabasi shramikko adhikaar. National Human Rights Commission, Nepal.

NRNA. (2020). Number of total infected among Nepali in middle eastern countries, Qatar, Saudi Arabia, UAE, Kuwait, Bahrain and Oman: May 3-Jul 11, 2020. https://www.nrna.org/News/newsid/1671 (Accessed: 24.07.2020)

Oberoi, P. (2010). Empowering migrants: human security, human rights, and policy. Human Security and Non-Citizens. Cambridge University Press, Cambridge.

Pant, B.R. (2020 April 03). Migrant workers must not be left behind. The Kathmandu Post. https://kathmandupost.com/columns/2020/04/03/ migrant-workers-must-not-be-left-behind (Accessed: 24.06.2020)

Prasain, S. \& Mandal, C.K. (2020a June 17). Supreme Court orders government to use welfare fund to repatriate Nepali workers stranded abroad. The Kathmandu Post. https://kathmandupost. com/national/2020/06/17/supreme-court-orders-government-touse-welfare-fund-to-repatriate-nepali-workers-stranded-abroad. (Accessed: 28.06.2020)

Prasain, S. \& Mandal, C.K. (2020b June 07). Authorities plan to rescue Nepali stranded abroad. But no one knows who will pay for it. The Kathmandu Post. https://kathmandupost.com/national/2020/06/07/ authorities-plan-to-rescue-nepalis-stranded-abroad-but-no-oneknows-who-will-pay-for-it. (Accessed: 28.06.2020)

Seddon, D. (2005). Nepal's Dependence on Exporting Labor. Migration Policy Institute. https://www.migrationpolicy.org/article/nepalsdependence-exporting-labor. (Accessed: 28.06.2020)

Sharma, G. (2020). Nepal's top court orders rescue of migrant workers stranded abroad. Reuters. https://www.reuters.com/ article/us-health-coronavirus-nepal-migrants-trf/nepals-topcourt-orders-rescue-of-migrant-workers-stranded-abroadidUSKBN21Z2DO(Accessed: 22.06.2020)

Shrestha, S.K. (2020). Covid-19 Crisis and Solution. Nepal Association of Foreign Employment Agencies (NAFEA) 
Tadjbakhsh, S. (2014). Human security twenty years on. Expert Analysis. Norwegian Peacebuilding Resource Centre. https://www.files. ethz.ch/isn/181368/540cb240aa84ac7133bce008adcde01f.pdf. (Accessed: 22.07.2020)

Teschke, B. (2003). The Myth of 1648: Class, Geopolitics and the Making of Modern International Relations. Verso, London

The Business Standard. (2020). Psychosocial support for migrant workers and their families - time to act from the policy level. https:// tbsnews.net/thoughts/psychosocial-support-migrant-workers-andtheir-families-time-act-policy-level-89752 (Accessed: 28.06.2020)

The Himalayan Times (2020). Govt to rescue Nepali stranded abroad 'on priority basis'. The Himalayan Times. https://thehimalayantimes. com/nepal/government-to-rescue-nepalis-stranded-abroad-onpriority-basis/ (Accessed: 18.06.2020)

The Kathmandu Post. (2018). Overseas ordeal: Govt aye to legal help for workers. https://kathmandupost.com/national/2018/06/29/govt-aye-tolegal-help-for-workers. (Accessed: 12.07.2020)

Tsourapas, Gerasimos. (2018). Authoritarian emigration states: Soft power and cross-border mobility in the Middle East. International Political Science Review. https://doi.org/10.1177/0192512118759902. (Accessed: 18.06.2020).

UNDP. (1994). Human development report 1994: New dimensions of human security. http://www.hdr.undp.org/en/content/humandevelopment-report-1994 (Accessed: 17.06.2020)

Vertovec, Steven. (2020). Covid-19 and enduring stigma. MAX-PLANCKGESELLSCHAFT. https://www.mpg.de/14741776/covid-19-andenduring-stigma (Accessed: 22.07.2020)

WHO. (2020).A guide to preventing and addressing social stigma associated with COVID-19. https://www.who.int/whodocuments-detail/a-guide-to-preventing-and-addressing-socialstigma-associated-with-covid- $\quad$ 19?gclid=CjwKCAjwiMj2BRB FEiwAYfTbCsrmHytXE4Q0_i7K4m0AB1VX3aYB1dRtJAAkyFzRHI2Hk9Jcw5yZxoCBBcQAvD_BwE (Accessed: 12.07.2020) 
146 NEPALI MIGRANT WORKERS AMID COVID-19 IN MAJOR DESTINATION ...

Wolfer, A. (1962). National security as an ambiguous symbol. Discord and collaboration. Johns Hopkins University Press, Baltimore

Yayboke, E. (2020). Five ways COVID-19: Is changing global migration. Center for Strategic and International Studies. https://www.csis. org/analysis/five-ways-covid-19-changing-global-migration (Accessed: 17.07.2020) 